\title{
Rukopisna zbirka Poemata i drugi pjesnički radovi Dragutina Antuna Parčića
}

\begin{abstract}
U arhivskoj ostavštini Staroslavenske akademije u Krku, pohranjenoj u Biskupijskom arhivu u Krku (BAK), čuva se mala rukopisna zbirka Poemata vrsnoga jezikoslovca i glagoljaša trećoreca Dragutina Antuna Parčića (1832. - 1902.). Ova bilježnica ručne tvorevine sadrži 11 Parčićevih pjesama. Sve su napisane u duhu vremena, u raznim svečarskim prigodama, kao npr. u čast austrijskog cara Ferdinanda, pape Lava XIII., Parčićeva zadarskog učitelja Urbana Stanića i slično. Posebnost njegove zbirke jest u tome što su pjesme napisane čak na trima jezicima: talijanskom, latinskom i grčkom. Premda su uglavnom posrijedi školski primjerci njegovih uradaka, oni nam otkrivaju solidnost i vrsnost tadašnjega načina učenja stranih jezika, ali i Parčićevu nadarenost. Veće pak značenje među njegovim pjesničkim radovima imaju one pjesme ispjevane u kasnijoj fazi njegova života na staroslavenskom i hrvatskom jeziku. Ovdje spadaju i neka njegova pisma pisana u lirskom slogu. U njima otkrivamo neke manje poznate biografske podatke o Parčiću, kao i njegovu ljubav i odanost prema papi Lavu XIII., koji je pokazao posebnu naklonost prema slavenskim narodima i staroslavenskoj kulturi. U Parčićevo pjesničko stvaralaštvo ubrajamo i njegov probni pokušaj prevođenja Danteove Božanske komedije. Nju je, kako sâm bilježi, ponašio za pokus, tj. preveo na hrvatski jezik te 1875. eksperimentalno tiskao u svojoj tiskari „Serafinski tisak" u trećoredskom samostanu na Glavotoku na otoku Krku.
\end{abstract}

Ime Dragutina Antuna Parčića (Vrbnik, 26. svibnja 1832. - Rim, 25. prosinca 1902.) nećemo naći ni u jednoj pjesničkoj antologiji, niti ga šira javnost poznaje kao pjesnika. O njemu su napisane brojne studije, koje ga prikazuju kao vrsnog jezikoslovca i glagoljaša, kao priređivača posljednjeg glagoljskog misala, pionira fotografije u Hrvatskoj i leksikografa, vrsnoga prirodoznanstvenika u raznim granama. No, u svojoj univerzalnosti, po kojoj ga možemo ubrojiti među polihistore ili enciklopediste, okušao se u još jednom umijeću - pjesništvu. Istina, njegove pjesme nisu tiskane kao lirske zbirke i stoga nije ostavio knjiški tiskani trag pjesničke riječi, ali ono što je sačuvano u raznim rukopisima i prigodno otisnutim čestitarskim odama, a napisano je u stihovima, osim literarne vrijednosti, donosi i vrijedne autobiografske podatke o Parčiću, koji nam inače nisu poznati. K tomu, njegove pjesme još dublje otkrivaju njegovu erudiciju, visoku naobrazbu, koju je stekao u svojoj mladosti u samostanskim školama svoga franjevačkoga reda, te njegovu nadarenost i marljivost. 
Tako se u arhivskoj ostavštini Staroslavenske akademije u Krku, pohranjenoj u Biskupijskom arhivu u Krku ${ }^{1}$, čuva mala rukopisna zbirka pjesama Dragutina Antuna Parčića pod nazivom Poemata. ${ }^{2}$ Ova bilježnica ručne izrade, veličine 16 x $21 \mathrm{~cm}$, ima svega 24 stranice, a od toga posljednjih 7 neispisanih, te sadrži 11 Parčićevih pjesama, napisanih u duhu vremena, u raznim svečarskim prigodama. Posebnost njegovih pjesama jest u tome što su napisane na trima jezicima: talijanskom, latinskom i grčkom. Prema vremenu nastanka, uglavnom su to školski primjerci njegovih uradaka, napisani u njegovoj mladenačkoj dobi, između šesnaeste i dvadesete godine, koji nam otkrivaju solidnost i vrsnost tadašnjeg načina učenja stranih jezika, ali i Parčićevu nadarenost. No, za nas veće značenje njegovih pjesničkih radova imaju pjesme ispjevane na hrvatskom i staroslavenskom jeziku, koje su nastale u njegovoj zreloj dobi. Ovdje spadaju i neka njegova pisma pisana u lirskom slogu. U njima otkrivamo neke manje poznate biografske podatke o Parčiću, kao i njegovu ljubav i odanost prema papi Lavu XIII. (1878. - 1903.), koji je pokazao posebnu naklonost prema slavenskim narodima i njihovoj staroslavenskoj kulturnoj baštini, uzdignuvši štovanje Svete braće Ćirila i Metoda na razinu opće Crkve.

\section{Parčićevo pjesništvo u rukopisu Poemata}

Parčićevo pjesništvo možemo podijeliti na dvije faze: mladenačko i pjesništvo njegove zrele dobi. U mladenačko pjesništvo ubrajamo upravo njegov rukopis: Poemata. ${ }^{3}$ Ta rukom šivana bilježnica od 24 stranice zelenkaste boje ima ispisanih svega 15 stranica te sadrži šest pjesama na talijanskom jeziku, četiri na latinskom i jednu pjesmu na grčkom jeziku, sveukupno 11 pjesama.

Ono što iznenađuje kod Parčića jest to da u njegovom mladenačkom razdoblju ne nalazimo nijednu pjesmu napisanu na hrvatskom jeziku. Prvu koju je unio u svoju bilježnicu jest pjesma na talijanskom jeziku L'inverno (zima $)^{4}$, u kojoj bogatstvom emocija opisuje zimsku idilu. Pjesma sadrži svega četiri strofe.

Drugu je pjesmu, također na talijanskom jeziku, posvetio rimskom pjesniku Marku Tuliju Ciceronu, s jednostavnom posvetom: A Tullio (Tuliju). ${ }^{5}$ Ne navodeći vanjske motive ove posvete, očito je to odjek školskog učenja latinskog jezika na Ciceronovim tekstovima.

U sljedećim bilješkama: BAK.

2 BAK, Krk, Parčić, kut. 2, svežanj 1. Usp. VELČIĆ 2004: 37-52.

3 U Prilogu br. 1 ovoga rada donosimo transkribiran cjelovit sadržaj rukom ispisane bilježnice: Parcich-Poemata.

4 Parcich-Poemata: 3.

5 Isto: $3-4$. 
Treća je pjesma isto na talijanskom jeziku i prva u nizu prigodnih tekstova $u$ duhu vremena - Sonetto ${ }^{6}$ Riječ je o sonetu ispjevanom u čast austrijskom caru Ferdinandu I., prigodom njegova rođendana. Mogao je to biti jedan školski zadatak u onodobnim školama te ga je Parčić naslovio: Pel natalizio di Sua Maestà Imperiale, Reale Altezza Ferdinando Primo - 1848., tj. povodom rođendana njegova carskog i kraljevskog veličanstva Ferdinanda prvoga - 1848. Ovdje poziva svoju lirsku muzu sa željom da „Veliki graditelj“, kako naziva Boga, caru produlji vladalačke dane.

Ispod kratkog soneta slijedi himna - Inno ${ }^{7}$, također na talijanskom jeziku, opet u čast caru Ferdinandu, gdje s puno patetike i uzvišenosti izražava odanost caru:

Noi andremo sempre amando

Il vesillo e l'alto brando

Di Fernando Imperator.

U svakoj kitici himna završava usklikom:

Dio! conservi lungamente

Ferdinando Imperator!

Nakon ovih četiriju pjesama na talijanskom jeziku Parčić u svoju bilježnicu unosi prvu odu $-O d e^{8}$, na latinskom jeziku. I ova poduža oda napisana je u čast carskom veličanstvu, kojega samo u zadnjoj strofi apostrofira zajedno sa zemljom Austrijom:

Fac super nos pax veniat perennis

Austriae terras spatietur omnes

Atque per multos ea Ferdinandum Protegat annos.

Nakon ove poduže pjesme na latinskom jeziku napisao je još jednu odu, i to na grčkome, opet u čast Ferdinandu, naslovivši je:

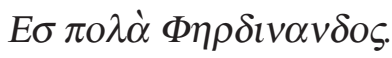

Završava usklikom:

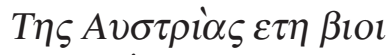

$E_{\zeta} \pi \circ \lambda \dot{\alpha} \Phi \eta \rho \delta \imath v \alpha v \delta o \varsigma$.

\footnotetext{
6 Isto: 5.

7 Isto: $5-8$.

8 Isto: 8-10.
} 
Nakon ovih četiriju pjesama u čast caru Ferdinandu, napisanih na trima jezicima, Parčić na 11. stranici svoje male bilježnice prelazi na drugu osobu. Nastavlja svojim epigramima, ali sada u čast svojem školskom učitelju, redovniku Urbanu Staniću, povodom njegova imendana. Bio je to profesor humaniteta, tj. profesor humanističkih - gimnazijskih razreda u zadarskoj tzv. Scuoli Pii. Pjesme je naslovio: Epigramma ${ }^{9}$, nadnaslovom: Die Onomastica R. P. Urbani Stanich, primae Humanitatis classis praeceptoris - discipuli. Ova je pjesma i datirana: Jaderae, VIII Cal. Junias 1848., tj. 25. svibnja 1848.

Godinu dana kasnije, istim povodom i istom profesoru u čast, napisao je sonet na talijanskom jeziku, ovaj put naslovljen: Pel felicissimo Onomastico di P. Urbano Stanich delle Scuole Pie Professore del secondo anno d'Umanità ${ }^{10}$, a datiran je: Zara 25 Maggio 1849. Iste godine i istog dana, 25. svibnja 1949., napisao je i drugu Epigrammu istom učitelju, povodom njegova imendana, na latinskom jezi$\mathrm{ku}$ - Ad Honomasticum P. Urbani Stanich Scholar. Piar. Epigramma ${ }^{l l}$ - Epigram za imendan ocu Urbanu Staniću (učitelju) „Pobožnih škola“.

Šestu po redu talijansku pjesmu naslovio je: Amore e luce ${ }^{12}$ - Ljubav i svjetlo. U njoj se mladi Parčić uzdiže prema Bogu, koji je stvaralačka ljubav i pravo svjetlo. Ova je pjesma potpisana inicijalima: F. C. P., tj. Fra Carlo Parcich. Zadnja je pjesma u bilježnici, a četvrta po redu na latinskom jeziku, oda prigodnica u čast Isusovu rođenju, jednostavnog naslova: Nativitas D. N. J. C. ${ }^{13}$ - Porođenje Gospodina našega Isusa Krista. To je druga pjesma religioznog sadržaja u ovome rukopisu, vezana uz kalendarski, kršćanski blagdan te je potpisana Parčićevim inicijalima F. C. P. i godinom 1852. Stranice koje slijede, od 18. do 24., prazne su.

Dakako, sve ove Parčićeve pjesme zahtijevaju daljnje jezično istraživanje i pjesničko vrednovanje te, $\mathrm{k}$ tomu, rekao bih, dodatnu verifikaciju autentičnosti autorstva. Naime, do sada jedino krčki povjesničar Mihovil Bolonić, koji usputno spominje ovaj Parčićev rukopis, nije ni dopustio sumnju u Parčićevo autorstvo ovih pjesničkih zapisa ${ }^{14}$, makar su pjesme nastale između 1848. i 1852., tj. u vrijeme kad je Parčić imao tek šesnaest, odnosno dvadeset godina. S obzirom na njegovu mladost, imamo pravo sumnjati u to je li se već tada mogao pjesnički i pismom izražavati na trima stranim jezicima, tj. na talijanskom, latinskom i grčkom, što nesumnjivo ide u prilog njegovoj izvanrednoj nadarenosti i marljivosti.

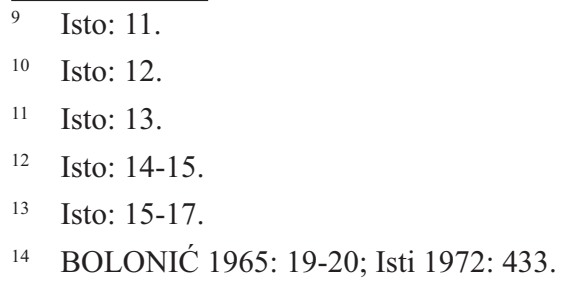




\section{Parčić kao hodočasnik u Rimu}

Za ostale Parčićeve pjesme iz kasnijeg razdoblja njegova života nema ni trunka sumnje u njihovu autentičnost. One su nastale u njegovoj zreloj dobi. Tako je prilikom boravka u Rimu 1870., kada je bio gost, odnosno domaćin u generalnoj kući svoga reda uz baziliku sv. Kuzme i Damjana na Fori imperiali, ispjevao dva soneta, oba na talijanskom jeziku. Prvi je naslovio dvojezično, na staroslavenskom i latinskom, pod motom: „Ne boj se maloje stado - Nolite timere pusillus grex“15, datiravši ga 2. veljače 1870., a potpisan je glagoljskim inicijalima. Spomenuti je sonet posvetio o. Luigiju, kardinalu protektoru franjevačkoga reda. ${ }^{16} \mathrm{U}$ njemu svoju redovničku zajednicu vidi kao maleno stado, koje Bog čuva i vodi, te se u tome nazire skromnost $\mathrm{i}$ jednostavnost svetoga Franje, osnivača reda.

Drugi je sonet datiran deset dana kasnije, 12. veljače 1870., pod motom: „Sinovi tvoji iz daleka doći i hćeri tvoje sa strane podignut će se“, također s njegovim glagoljskim inicijalima. Taj Sonetto - Sonet ${ }^{17}$, napisan na talijanskom jeziku, pjeva o mnoštvu hodočasnika koji hrle u Rim ,sa nordijskih i slavenskih putova“" ${ }^{\text {"18 }}$, ali se $\mathrm{u}$ isto vrijeme prije povratka $\mathrm{u}$ domovinu toplo zahvaljuje i oprašta sa svojom redovničkom, trećoredskom zajednicom u Rimu, koja ga je srdačno primila. No, njegovo srce ipak više kuca prema domovini kojoj se vraća, izražavajući to ovom usporedbom:

Non dico che si stia

Ivi meglio di qui, ma ad ogni augello

Più dell'altrui il proprio nido è bello. ${ }^{19}$

Doista, svakoj je ptici njezino gnijezdo najljepše, pa tako i Parčiću njegova domovina. Završava ovom rimom:

Finito c'il mio soggiorno;

Perciò pregando il celestal ajuto

Lascio a tutti un cordial saluto.

$D P$

\footnotetext{
15 Vidi Prilog br. 2.

16 Usp. BOLONIĆ 1965: 19.

17 Vidi Prilog br. 3.

18 Usp. Parcich - Poemata: 15. „Mosser le genti per diverse strade - Piene di fe' dal gimino emisfero - Da nordiche e slaviche contrade - Il centro a rimirar del sommo vero".

19 Usp. Parcich-Poemata: 16.
} 


\section{Parčićevo rimsko razdoblje}

Budući da mu njegova malena i siromašna provincija franjevaca trećoredaca glagoljaša (TOR) nije mogla priskrbiti mjesto, gdje bi se mogao nesmetano posvetiti radu za kojim je čeznuo, tražio je prostor na kojem bi imao slobodnije i šire polje za svoj rad. Radi toga se, ostajući uvijek i dalje u dobrim odnosima sa svojom redovničkom subraćom, 20. travnja 1876. ekskardinirao, odnosno sekularizirao; prema preporuci đakovačkog biskupa Josipa Jurja Strossmayera, postao je kanonik hrvatske crkve sv. Jeronima u Rimu te se kao takav mogao potpunije posvetiti svojim planovima, među kojima je bilo i tiskanje posljednjeg glagoljskog Misala, realiziranog 1893.

Dvije godine nakon Parčićeva dolaska u Rim na papinsku je stolicu 1878. zasjeo kardinal Gioacchino Vincenzo Pecci, koji je uzeo ime Lav XIII. Njegovim je dolaskom liturgijskom staroslavenskom jeziku zarudjela zora bolje budućnosti. Svoje osjećaje i ljubav prema slavenskim narodima pokazao je poznatom enciklikom Grade munus od 30. rujna 1880. Ta je okružnica pokrenula veliko zahvalno slavensko hodočašće u Rim 5. srpnja 1881., koje je Parčić oduševljeno pozdravio, kako to navodi njegov životopisac, posebnim pjesmama: hrvatskim i staroslavenskim. $^{20}$

\section{a) Tri Parčićeve pjesme na staroslavenskom jeziku}

U tom je rimskom razdoblju Parčić napisao tri pjesme na staroslavenskom jeziku. Na običnom je komadu papira pri vrhu napisao: Slavo Antico - Il Sinodo plenario in America, tj. Staroslavenski jezik - plenarni sinod u Americi, a u nastav$\mathrm{ku}$ je toga naslova na staroslavenskom ispjevao pjesmu - prigodnicu, datiranu 1. prosinca $1883 .{ }^{21} \mathrm{Te}$ se, naime, godine u Rimu sastala nekolicina američkih biskupa s ciljem sazivanja III. sabora u Baltimoreu (1884.), a tom su prigodom predstavili izvješće o migrantima u Sjevernoj Americi. ${ }^{22}$ Pritom su izrazili svoju zabrinutost prema brojnoj i nagloj nadolazećoj emigrantskoj talijanskoj etničkoj skupini, koja

20 DAROSLAV 1903: 19-20. Daroslav (pseudonim Kvirina Klementa Bonefačića) navodi u bilješci završetak jedne takve Parčićeve pjesme na hrvatskom i staroslavenskom jeziku, koju ne nalazimo u njegovoj arhivskoj ostavštini, stoga je preuzeta iz Daroslava: (...) Ciril, Metod ta braća solunska - Svjetlom vjere njega obasjaše, - A sa vjerom divno osvetiše - Milo slovo domaćeg jezika. - Slava Tebi, Ivan Papa osmi. - Što si začô misal plemenitu, - Slava Tebi, Lave trinaesti, - Što si širom vasiona svieta - Neumrlu Braću razglasio, - A Slavjanom krepko naglasio: - Da sjate se svi u jedno stado - Jedno stado pod jednim Pastirom, - Rimskim Papom čvrstim Crkve stupom! - I na staroslavenskom jeziku: (...) Toju slavet'se naukom - Česi, Panon'ci, Bl'gari, - Hr'vati, južni žitele, -V'Dalmacii, po ostr 'vêh'. - Vsi kup 'no dn's v'zglasajut'-Slavu Kurilu, Metodu; - Ošte že v'sa v'selenija - K'de sut'vêrnici Hristovi. - To L'v'tretij'na deseti - Hr 'stjanskim' 'ljudem 'povelê, - Da brat'ska druž'ba v'Slovêneh, - Jedin 'stvo veri pospêsit'.

21 Vidi Prilog br. 4/I.

22 TERRAGNI. www.chiesacattolica.it (posjet 17. 7. 2015). 
je bila obilježena nepismenošću, nepoznavanjem engleskog jezika i rudimentalnom religioznošću, koja je za tamošnje, mahom irske katolike, graničila s poganstvom i praznovjerjem. U isto su vrijeme, za Parčića, to masovno iseljavanje u Ameriku u drugoj polovini 19. stoljeća, ponajviše Talijana, ali i pripadnika slavenskih naroda, kao i njihova integracija u američku Crkvu, predstavljali priliku za širenje Crkve i stvaranje novog zajedništva s papom Lavom XIII. Taj tadašnji aktualan događaj u povijesti Katoličke crkve u Americi, zahvaljujući Parčiću, zabilježen je, dakle, i na staroslavenskom jeziku, a započinje riječima: „Slavno drevo debla golemago ..." ${ }^{\text {"23 }}$ Ova je pjesma potpisana Parčićevim inicijalima s glagoljskim slovima. Druga pjesma na staroslavenskom jeziku nosi naslov, olovkom pribilježen: Slavjem Lavu XIII (trinadesetomu). ${ }^{24} \mathrm{U}$ toj pjesmi Parčić izražava svoju odanost papi Lavu XIII., velikom prijatelju Slavena. Zato u trećoj kitici pjeva:

Smerni ti narod Kurila, Metoda,

Plečeti i poeti, Arhiereistva radi

Slavna Tvoego, Petdeseta goda

Pesmi nasladi. ${ }^{25}$

Prema ovim stihovima, navedenu, inače nedatiranu pjesmu, možemo datirati u godinu 1888., prigodom 50. obljetnice njegova svećeničkog jubileja. Naime, papa Lav XIII. zaređen je za svećenika 31. prosinca 1837., ali možemo je povezati i s proslavom 50. obljetnice njegova biskupskog posvećenja jer je za nadbiskupa zaređen svega šest godina kasnije, tj. 1843., pa je moguće da ju je Parčić ispjevao 1893., tim više jer spominje ,,arhiereistva radi“ “. ${ }^{26}$

Treću je staroslavensku pjesmu Parčić posvetio sv. Kolumbu, franjevcu, kao i papi Lavu XIII. ${ }^{27}$ I ova je pjesma napisana povodom 50. obljetnice njegova svećeničkog ili biskupskog ređenja jer u zadnjoj strofi Parčić ovako pjeva:

V'zdaždi se ubo v'našem d'nes' narode

L'vu hvala, čst, blagodet'prava:

$V$ 'petdesetom Osvemjenija gode

Vsi da v'skliknem' silnu L'vu slava! ${ }^{28}$

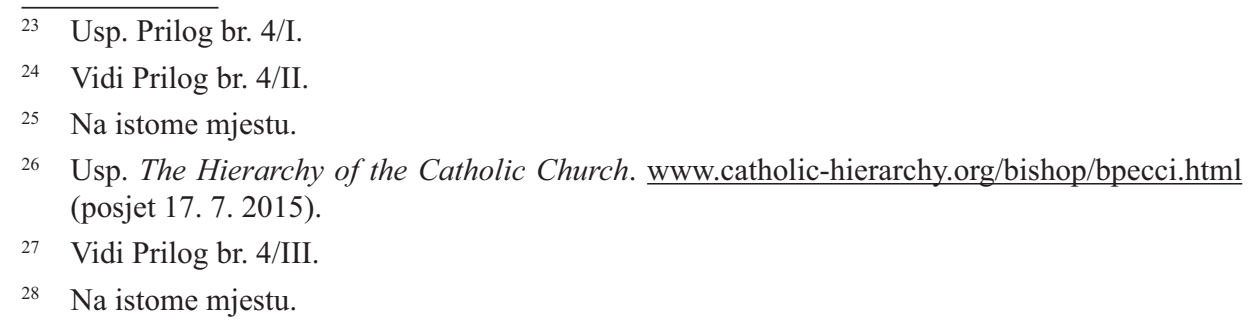


b) Još jedna pjesma u čast papi Lavu XIII.

Parčić je svojim boravkom i radom u Rimu mogao izbliza pratiti crkvena zbivanja onoga vremena. Svoje divljenje i zahvalnost prema papi Lavu XIII. izrazio je i u drugim dvjema pjesmama, jednoj na hrvatskom, a drugoj na talijanskom jeziku.

Pjesma ispjevana na hrvatskom jeziku ima, očito kasnije dodan, talijanski naslov: Giubileo sacerdotale di Leone XIII, 1888. Voti ed aspirazioni del pellegrino Italiano. ${ }^{29} \mathrm{U}$ njoj Parčić, uz divljenje prema papi i njegovoj službi koju ima u „Katoličkoj vasionskoj Crkvi“, izražava i svoje gledanje na papinsku svjetovnu vlast nad Rimom i papinskom državom i to upravo u vrijeme kad je papa, oduzimanjem papinske svjetovne vlasti, postao vatikanski zatočenik talijanskog ujedinjenog kraljevstva. Zato Parčić ovako pjeva na hrvatskom govornom jeziku, gdje obilato koristi i staroslavenske i čakavske riječi/idiome:

Kuda kreće množina naroda,

Kamo 'I hrli svetom pobožnosti?

(...)

Sve to vrvi k Rimu bijelome

A pred noge Papi Velikome;

Jedna misal, jedna vlada želja

U bezbrojnih hodočastnih srdcih,

Trinadesetog da posjeti Lava

Što Petrovom upravlja Stolicom.

Da iskažu čuvstvo prirodjeno

Jeda mu se sloboda povrati

Kû mu svjetska uzkraćuje sila,

Da u Rimu sa svoga središta

I ko Vladar i Namjestnik Božji

Bez utruhe ine ljudske vlasti

Sam svoj bude i dušom i tjelom;

Odkud širi nauk ćudoredni

I tumači svete vjere članke

Katoličkoj vasionskoj Crkvi. ${ }^{30}$

O tome koliko je Parčić među svojim suvremenicima slovio kao pjesnik svjedoči nam i pismo njegova subrata, trećoreca fra Pija Dujmovića ${ }^{31}$, koji ga 7.

\footnotetext{
$29 \quad$ Vidi Prilog br. 5.

$30 \mathrm{Na}$ istome mjestu.

31 O. dr. Pijo (Pavao) Dujmović, TOR, rođen u Portu (Dubašnica) 20. studenog 1870., a za svećenika je zaređen u Zadru 1894. U Rimu je postigao doktorat iz filozofije i teologije. Bio je
} 
kolovoza 1901., tj. godinu dana prije Parčićeve smrti, moli da napiše pjesmu na staroslavenskom jeziku povodom ustoličenja novog zadarskog nadbiskupa. O. Pijo Dujmović piše mu sljedeće:

„(...) prisiljen sam da Vam se pismeno javim, te zamolim za jednu ljubav. Nemojte se prestrašiti, ne radi se o velikom pitanju, stvar to za Vas sasvim lahka. Kako Vam valjda poznato, nabrzo će amo novi Nadbiskup. Svi će nastojat, da naprave što bolju figuru. Bit će u obilju sastavaka u talijanskom, latinskom pa možda i kineškom jeziku... A bilo bi dostojno, da (r/v) se i glagoljica pomoli na obzorju. Kad bilo prigodom ustoličenja pt. Rajčeviću ${ }^{32}$ mi napravili sjajnu figuru sa Vašom pjesmom glagoljskom, koju ste bili učinili za pt. Feretića. ${ }^{33}$ Trebno bi nam dakle i sada takvi sastavak glagoljski, a tko bi bio kadar to učiniti? Nijedan, nego Vi Prečastni. Neka dakle još jednom zapjeva Vaša vila u miloj glagolici. Blagoizvolite nam dakle učiniti tu prigodnu pjesmu. Bit ću Vam u velike haran i zahvalan. Držim da netreba drugo, te smo se podpuno razumili““. ${ }^{34}$

Takvo je mišljenje imao O. Pijo Dujmović o Parčiću! Iz ovoga pisma proizlazi da je Parčić najvjerojatnije napisao još jednu prigodnu pjesmu na glagoljici, odnosno na staroslavenskom jeziku za novoga zadarskog nadbiskupa Mateja Dujma Dvornika (1901. - 1910.), kao što je to napisao ranije i povodom ustoličenja krčkoga biskupa Franje Anijana Feretića (1880 - 1893.). Tu je pjesmu za biskupa Feretića na staroslavenskom jeziku tiskao glagoljicom u papinskoj tiskari „De propaganda fide“ u Rimu. ${ }^{35}$ Je li Parčić uspio ispuniti i Dujmovićevu želju nije nam poznato.

Slična prigodna čestitanja u stihu Parčić je izvodio i prigodom svećeničkih ređenja i slavlja mladih misa, ali i prilikom polaganja redovničkih zavjeta. ${ }^{36}$ No, znamo za još jedno pismo koje je Parčić u stihu napisao svome ujaku, vrbničkom

tajnik provincije i u nekoliko madata provincijal, a 1912. imenovan je generalom Reda. Umro je u Zagrebu 21. srpnja 1935. te je pokopan na Mirogoju. Usp. BOZANIĆ 2012: 105-106.

32 Zadarski nadbiskup Grgur Rajčević (1891. - 1899.) rođen je 30. siječnja 1826. u Dubrovniku. Za svećenika je zaređen također u Dubrovniku 30. rujna 1848., a za zadarskog nadbiskupa zaređen je u Zadru 27. prosinca 1891. Umro je u Zadru 25. listopada 1899. Protivio se glagoljanju u liturgiji. Usp. The Hierarchy of the Catholic Church. www.catholic-hierarchy.org/bishop/brajc. html (posjet 19. 7. 2015).

33 Krčki biskup Franjo Anijan Feretić (1880 - 1893.) rođen je u Vrbniku 3. prosinca 1816. Zaređen je za biskupa u Gorici 23. svibnja 1880. Kao biskup virilist bio je zastupnik u Istarskom saboru u Poreču, snažno braneći hrvatske interese, od jezičnih do gospodarskih. Usp. BOZANIĆ 2012: 109-110.

34 BAK, Krk, Parčić. Pismo je sačuvano u kut. 2, sv. Korespondencija Parčićeva, II. nastavak Slučaj sv. Jeronima.

35 Usp. BOLONIĆ 1965: 20.

$36 \mathrm{Na}$ istome mjestu. M. Bolonić navodi da je Parčić u svojoj tiskari na Glavotoku tiskao razne sonete prigodom mladih misa o. Alfonza Mršića (1884.), o. Stanka Dujmovića (1888.) i o. Pija Dujmovića (1892.) (tih je godina, naime, Parčić bio u Rimu, pa je to najvjerojatnije mogao izvesti za vrijeme ljetnih praznika, kada je rado dolazio u Glavotok, op. a.). 
pučkom pjesniku i povjesničaru Josipu Antunu Petrišu. ${ }^{37}$ Naime, Petriš je svoja pisma u stihu pisao svom nećaku Parčiću. Budući da se jedno Petrišovo pismo u stihu sačuvalo u Parčićevoj ostavštini, donosimo ga u prilogu ovome radu. ${ }^{38}$ Parčić mu u svom odgovoru također iznosi brojne precizne podatke o prilikama u svojoj obitelji, o svom bavljenju fotografijom ili svjetlopisom, kako ga on naziva, kao i druge autobiografske podatke. ${ }^{39}$ Evo kako Parčić u stihu bilježi primitak ujakova pisma, dospjelog 11. svibnja 1862., a već 18. svibnja šalje mu odgovor:

Miloglasna jedna ptica

Čudnovata crna i bila

K Manastiru od Školjića

Iznenada doletila!

Jedanaest danak svibnja

Na dospitku jur biaše

Kad mi ova ptica divna

Lipu pisan pripivaše.

(...)

Knjigu moju sad dospivam

Svibnja dne osamnajstoga

Svako dobro Vam nazivam

Od milosti Svemogoga.

Ujče, dragi želim vruće

Poživio nam na dugo.

Pisah u lito tisuće

Osam sto šestdeset drugo.

F. Ant. Parčić. ${ }^{40}$

No, u Parčićevo pjesničko stvaralaštvo smijemo ubrojiti i njegov eksperimentalan pokušaj prevođenja Danteove Božanske komedije, koju je, kako sam bilježi, ponašio za pokus, tj. preveo ju je na hrvatski jezik i 1875. eksperimentalno

37 Usp. PETRIS 2010: 280. Prirediteljica knjige Tanja Perić-Polonijo o korespondenciji Petrisa i Parčića piše: „U tim je pjesmama Petris više kroničar onog vremena negoli pjesnik. Posebno su dirljive pjesme - prepiske između J. A. Petrisa i njegova nećaka, trećoredca Antona Dragutina Parčića, koje odišu međusobnim uvažavanjem i ljubavlju“.

38 Vidi Prilog br. 6.

39 Vidi Prilog br. 7.

$40 \mathrm{Na}$ istome mjestu. 
tiskao u svojoj tiskari u trećoredskom samostanu na Glavotoku na otoku Krku. ${ }^{41}$ To je početak Danteova spjeva Pakla. Sve je tiskarske radnje pri tom poslu, kao urednik, prevoditelj, grafički i likovni urednik, Parčić učinio sam. Želeći pod svaku cijenu izbjeći aloglotem, Danteov spjev nazvao je „mudropojkom“, a taj se prepjev smatra prvim hrvatskim prijevodom Danteova Pakla, objavljenim u obliku knjige. ${ }^{42}$ To maleno djelo ima svega 12 stranica, formata $13 \times 20 \mathrm{~cm}$, a Parčić ga je posvetio svom redovničkom subratu „Pošt. Ocu Stjepanu Ivančiću Trećega Reda sv. Frana“"43, prigodom njegove mlade mise 17. siječnja 1875. Tu je posvetu ispisao na lijepo ukrašenoj trećoj stranici u obliku mramorne spomenploče, a na samoj naslovnici ispod godine izdanja 1875. glagoljskim je slovima otisnuto - „Serafinski tisak““ ${ }^{44}$

\section{Umjesto zaključka}

Ime i djelo Dragutina Antuna Parčića u hrvatskoj povijesnoj leksikografiji, glagoljaškoj baštini, povijesti fotografije i u drugim granama znanosti sve više zauzima pripadajuće mjesto. No, postoje još razni segmenti njegova stvaralaštva koje valja istražiti i pravilno vrednovati. Zacijelo među njegove manje poznate doprinose našoj kulturnoj povijesti smijemo ubrojiti pjesničke izričaje. Na temelju ovih, do sada prikupljenih, mahom slabo poznatih, Parčićevih lirskih uradaka možemo mu, uz brojna druga zalaganja i stvaralaštva, pridodati i pjesničko nadahnuće, koje je ostavio u raznim pjesničkim zapisima.

$\overline{41}$ Iscrpnu studiju o maloj tiskari na Glavotoku koju je Parčić osnovao, vodio i nazvao „Serafinski tisak" vidi BOLONIĆ 1965.

42 Usp. GOSTL 1998: 83.

43 BAK, Parčić, kut. 2, svežanj 1.

44 Treba napomenuti da na glagoljskom otisku ne piše „Serafinski“ već „Serafimski“! Dakako, u hrvatskom govornom izričaju koristi se oblik „Serafinski“. 
Prilog br. 1.

Str. 1.

Parcich

POEMATA

Str. 3.

L’inverno.

Allorché l'Aquilon la verde selva Spoglia dell'onor suo squallido giace E incolto il campo e la crudele belva In un profondo obblio nell' antrotace. Insiem col ghiaccio la canuta neve Ingombra '1 suolo del terren ferace. Il fiume più non scorre agile e lieve, Ma grave e carco di gelato umore. Condensati vapori il sole beve

Che alla terra ne negan lo splendore.

Non s'ode degli augelli il dolce canto, Che negli affanni ci conforta ' 1 cuore.

Tutte le cose copre oscuro manto.

A Tullio.

O Tullio, cui nell'imo cuor io porto A cagion delle grazie a me concesse, E che grande al pensar piglio conforto Perchè per tua bontà special le stesse Tue sembianze una volta quiv' io vidi, Ed or posso veder e parlar spesse

Fiate e passeggiare in questi lidi

Str. 4.

Col dotto e saggio tuo fratel, che desta

Col ragionar la speme negl'infidi,

Narrommi tutte le tue eccelse gesta, 
Quante fatiche per l'onor di Dio,

Quante per consolar la patria mesta

Soffristi, e dell'onor per lo desio

Quante per le stampate opre e pe' versi

Co' quali dell' ingegno tuo natio

Dimostrasti il vigor tu che diversi

Contrari oggetti confrontare puoi

$E$ benchè vili di licore aspersi

Distendi il nome lor fino a' lidi Eoi:

Mi congratulo teco per l'umile

Questa tua impresa e a proseguirla poi

$\mathrm{T}$ ' animo nel finor cominciato stile,

Quantunque debba pria animato questi

Essere da te, il qual nel verde Aprile

Del pelago paventa le funesti

Ed orride procelle, mentre in fretta

Colla Musa pedestre a te codesti

Senza valor carmi scherzando detta.

Str. 5.

Pel natalizio di

Sua Maestà I. R. A.

Ferdinando Primo - 1848.

Sonetto.

Destati ormai dal lungo sonno, o Musa,

Ve' come chiaro il sol sul firmamento

Mandar la luce usata non ricusa,

Anzi par, che prorompa in lieto accento:

Oggi splender fa d' uopo alla rinfusa

E dare a tutti gli esseri argomento

Che i loro prieghi a suon di Cornamusa

Mandino in cielo e la mestizia al vento:

Destati a dunque, e le sorelle invita,

Che teco un' inno intuonin lacrimando;

Affinchè '1 sommo Fattor i dì di vita

Si degni prolungar a Ferdinando,

Che l' opre sue governi, e dell' avita

Sede sia degno e del paterno brando. 
Inno

Piaccia ad altri il mese Aprile, Altri ambiscan il Natale, Anteceda ogni stagione La stagion Primaverile Cinta il capo di corone

Str. 6.

Noi andremo sempre amando

Il vessillo e 1'alto brando

Di Fernando Imperator.

O supremi generali, Che lo sciame governate Della turba guerriera Siete esposti a' duri strali Della furia straniera Esclamate unitamente: Dio! conservi lungamente Ferdinando Imperator!

O fedeli guerrieri, Che la vita consecraste Per la vita del Monarca, V' esponeste a' destin feri Che vi manda l'altra Parca Esclamate unitamente: Dio! conservi lungamente Ferdinando Imperator!

$\mathrm{O}$ vassalli fortunati

Che dell' Austria possedete Le pianure e le colline, Folte selve e i verdi prati E le spiagge al mar vicine Esclamate unitamente

Str. 7.

Dio! conservi lungamente Ferdinando Imperator! 
O pastore fortunato,

Che d' un faggio all' ombra assiso

Colle vivide canzoni

E col suono modulato

Offri a Pan dovuti doni

Deh! esclama pïamente:

Dio! conservi lungamente

Ferdinando Imperator!

O meschino tapinello,

Che di cenci ricoperto

Vai poggiato ad un bastone

Accattando ad ogni ostello

Pan con umile sermone

Deh! esclama pïamente:

Dio! conservi lungamente

Ferdinando Imperator!

O felici pecorelle,

Che di Tibia al dolce suono

Del pastor al canto lieto

Saltellate snelle, snelle

Sotto l'ombra dell' abeto

Esclamate bellulando

Dio! conservi Ferdinando

Str. 8.

Ferdinando Imperator!

O boscaglie avventurate,

Che de' rami sotto l'ombra

Accogliete il pastorello

Ne' coccenti dì d' estate

E 1' ignudo tapinello

Date un suon unitamente:

Viva, viva! lungamente

Ferdinando Imperator!

E noi tutti in questo giorno

D' allegrezza e di contento

Nostri voti in ciel mandiamo

Nell' angelico soggiorno

Ed uniti esclamïamo: 
Santo! Santo! eternamente

Dio! conserva lungamente

Ferdinando Imperator!

Ode.

Hic dies semper nitidus refulgat Caesari nostro celebres potenti Namque natales dedit et labentis Tempora vitae

Hic dies cordis replet ima nostri

Gaudio, grates referamus Illi

Str. 9.

Debitas suadet, simul et rogemus

Prospera ab alto:

O Pater, qui de solio superno

Principes, reges sapiens gubernas, Dexterâ qui illis retegisque jura Pandis et aquum.

Qui dies cunctos numeras eorum

Sistis et nutu, precor, ut benignus Imperatorem tueare nostrum

Dum colit orbem.

Effice ut plures valeat beatos

Integer soles nitidos videre, Pelle propensus piceas opaco Aere nubes:

Imperî seda rabidas procellas, Fac quies et pax dominetur alma Abditas regni gradiatur omnes Ipsa latebras.

Longius nigrae retrahant Sorores Invidos gressus, revocentque diras Longius mortes, abeant cruenta Proelia Martis Bellici nunquam capiatur aeris Auribus tristis sonitus nec ipse Acer armorum fragor atque pugna 
Str. 10.

Militis atrox.

Fac super nos pax veniat perennis

Austriae terras spatietur omnes

Atque per multos ea Ferdinandum

Protegat annos.

Fac, Deus, tandem, te humiles precamur,

Ipse quod, vitâ placide peractâ,

Sedibus coeli mereatur altis

Usque potiri.

Ode.

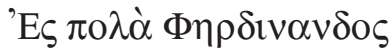

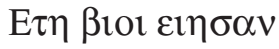

$\Pi \alpha \nu \tau \alpha \varepsilon v \tau v \chi \eta \varepsilon \vee \alpha v \tau o v \tilde{\omega}$

$\mathrm{K \varepsilon} \lambda \varepsilon v \sigma \mu \alpha \tau \imath \tau \varepsilon \pi \alpha \nu \tau \varepsilon \varsigma$

Y $\pi$ ò $\varepsilon ı \eta \sigma \alpha \nu \alpha \nu \tau \tilde{\omega}$.

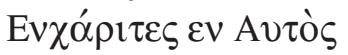

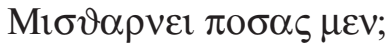

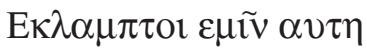

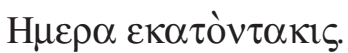

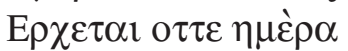

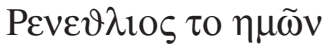

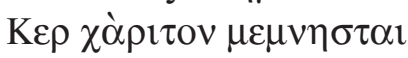

$\mathrm{A} \pi \mathrm{o} \delta \imath \delta 0 \sigma \imath \kappa \alpha \imath \alpha v \tau \tilde{\omega}$.

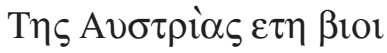

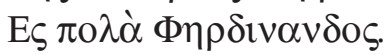

Str. 11.

Die Onomastica

R. P. URBANI STANICH

I.mae Humanitatis classis praeceptoris

Discipuli

Epigramma. 
Nominis alma Tui dum lux, Urbane, refulsit

Complevit grata' pectora nostra prece;

Supplicibusque simul votis replevimus auras

Haec alto edentes consona verba sono:

„Te Deus Omnipotens multos tueatur in annos,

Eveniantque Tibi prospera cuncta diu;

„Usque tuae doctus mentis sit praeses Apollo

Castoque accipiat docta Minerva sinu

„Tempora posteaquam vitae consumpseris hujus

Muneribus coeli promereare frui!“‘

Jadrae VIII Cal. Junias 1848.

Str. 12.

Pel felicissimo Onomastico

di

P. Urbano Stanich

delle Scuole Pie

Professore del secondo anno d' Umanità.

Sonetto.

Come solerte agricoltor, che a schiera

Svolazzar vede rondinelle amiche,

E con alterno pie' Ninfe pudiche

Il verdeggiante suol scuotere a sera,

Già s' accorge approcciar la Primavera;

Già le campagne rifiorir apriche;

E, che si degni serbar di sue fatiche

Il frutto; una al Fattor erge preghiera.

Così noi cui un nuovo alto piacere

Celer nel cuore in questo dì discese,

(Dì che del nome Tuo c'è forieriere,)

Il bramato desir facciam palese:

„Vivi, Urbano, gridiam già d' un volere,

„Ne' d' un sorriso tuo ci sia scortese.“

Zara 25. Maggio 1849. 
Str. 13.

Ad Honomasticum

P. Urbani Stanich Scholar. Piar.

\section{Epigramma.}

Visa mihi quando Aurorae sunt lumina flavae

Os obduxerunt splendidiora meum,

Astra jubar coelo dum cuncta deinde fugavit

Lumina tum emisit lucidiora dies.

Plurima suspenso mecum tunc corde volutans:

„Quae (?) talis, dixi, causa nitoris adest?

- „Dic, queso, (?) certis qui nutibus astra gubernas

(Si mea divinis jungere vota licet"-)

Tumque celer summo (?) demittitur (...) Divus

Qui dicit libero talia verba pede:

„Hic jubar Urbani praeclarum nomen honorat,

Omnia cui solers fausta memento roges.

Nîl posthac licuit mihi, eo volitante per auras

Dicere, (...): - „Faciat pandita vera Deus!“ -

Jadrae VIII Cal. Junias 1849.

Str. 14.

Amore e luce.

Pria che le liquide onde de' mari

Si rifrangessero ne' solitari

Lidi d' Esperia, prima che baci

Desse la tortora di fe' veraci

Amore fu.

Sempre con giubilo scherzando già

Presso la Vergine luce giulia

D' intorno lepido le saltellava

E le ancor pallide gote n' ornava

Di fior virtù. 
Ella di vivida cera e allegra

Allor faceasi; e benchè 'ntegra

Fatta sensibile premea l' amore

Perchè li palpiti n' oda del core

Caldo per lei.

Felice coppia chi mai v' unir?

Se non che l'ottimo Rettore e Dio?

Egli che l'opere perfette crea

Insiem convivere far non potea

Due cor che (...)!

Luce che lucido l'oscuro fai

$E$ in antro intimo protendi i rai

Per cui rivestesi del verde il prato

E il vis virgineo vien colorato

Di rosso blu,

Str.15.

Rischiara al giovine cor inesperto

Il vero tramite pel cammin erto

Si' che benefico lo tuo chiarore

Lo guidi all'apice, ove l'Amore

Regna lassù.

E tu che inanimi l'ampia natura

$\mathrm{Su}$ la cui faccia non v' ha creatura

Che se non aliti, Amore amato

Prendi l' omaggio che ti vien dato

Di servitù.

F. C. P.

Nativitas D. N. J. C.

Ode.

Caesaris Conjux veneranda jussu

Cum senes centi properat Josepho

Tramitem saevo retinente longum

Frigore et algu. 
Advenis Bethlem renuit colendis

Fracta qua ponant sua membra sedem,

Hinc simul quam penetrant miselli

Nocte cavernam.

Str. 16.

Protinus noctis tenebrae fugantur,

Luce frigescens radiatur aether,

Virginis casto generatur Infans

Ventre Redemptor.

Sede demittit Pater a superna,

Qui melos laetum modulentur ore, Angelos, magna et referant ad orbis

Nuncia Gentes.

Celitum visit vigiles canendo

Turba Pastores „Hilaresque, dicit, „volvite aspectus, adit en peracto „Tempore Salus.

„Eja vicinum properate ad antrum, „Atque, praesepi recubanti in arcto „Gloriam Infanti debitam benigno „Corde referte“.

Aspera divum stipula retectum

Hi propinquantes reperere natum

Cuique praebebant tepidos asellus

Bosque calores.

Supplices Regem venerantur almum, Cordium puras Domino precesque

Str. 17.

Exhibent, pleni redeuntque sancto

Tecta timore.

Anno 1852

F. C. P.

Str.18. - 24. Prazne! Kraj bilježnice Poemata. 
Prilog br. 2.

Ne boj se maloje stado

Nolite timere pusillus grex.

Sonetto

Non temer, picciol gregge, ne' Vangeli

Cosí ci parla il Salvator divino,

Che per quantunque umil tu sia e meschino

Verrai meco a goder lassú ne'cieli.

Cosí robusti s'ergono gli steli

Di senape, e un minuto granellino

Fa risorger da sè l'eccelso pino

Che paventar non sa le nevi e i geli.

Te pur, Luigi, nel pusillo gregge

Francesco accoglie tra seguaci suoi

Ilare dunque osservane la legge;

Che un ilare dator Iddio compensa, Affinchè 'nsiem co'confratelli tuoi Possa fruir della celeste mesna.

Roma 2/2 870.

DP

Prilog br. 3 .

Sinovi tvoji iz daleka doći i hćeri tvoje sa strane podignut će se.

Filii tui de longe venient et filiae tuae de latere surgent.

Sonetto.

Mosser le genti per diverse strade

Piene di fe' dal gemino emisfero

Da nordiche e slaviche contrade 
Il centro a rimirar del sommo vero;

Si che può dirsi con tutta veritade

Come gli abitator dell'orbe intero

Vennero a visitar l'alma cittade

„Li siede il successor del maggior Piero“.

Me pur mosse la fè, mosse il desio;

E voi qui m'accoglieste in lieto viso

E ricover mi deste; si che il cor mio

Per tenerezza ne rimase acciso - (ne riman conguiso)

Or partendo da Voi che dir poss'io? -

-A rivederci insiem nel Paradiso - !

E non vi mova a riso

Se al Sonetto v'attacchi pur la coda

Chè così vuol del dì d'oggi la moda.

E se a qualcun chè m'oda

Questa non piaccia, se la getti via,

Chè senza d'essa può star la poesia.

Or dirò come si sia:

Che bramo rieder nel mio suol natale

Per la prossima fin del Carnevale.

E non par mica male

Se a riveder presto la patria mia

Acceleri pur del cammin la via.

Non dico che si stia

Ivi meglio di quí, ma ad ogni augello

Più dell'altrui il proprio nido è bello.

Dirò in aggiunta a quello

Che bramo dar un vale specialissimo

Al Padre Generale Reverendissimo

E al Priore Osservandissimo

E ai Maestri e Lettor che in questo giorno

Co' Sacerdoti e Laici stan d'intorno. 
Finito cèil mio soggiorno;

Perciò pregando il celestal ajuto

Lascio a tutti un cordial saluto.

Roma, 12/2 870

DP

Prilog br. 4.

Tri pjesme na staroslavenskom jeziku.

I.

Slavo Antico:

Il Sinodo plenario in America

Slav'no drevo debla golemago

Rasprostr'tim' vetviem' široko

Ot sl'n'č'nago zštićaet' vara

Po v'selenei pola, sela, gradi;

A' v' sred' vetvii raznolič'nim p'ticam'

Piću daet' i mir'no počitie.

V'sue bura, v'sue vih'r' ljuti

Pretit' emu; Nepodviž'no stoit'!

To drevo est' Cr'ki Isusova

V'sego mira kon'ce ob'emljući;

A naipače krep'ko korenie

V'Americe sil'nei v'lagajući,

Živo rastit', plodom' obiluet'.

Tamo kita mudrih' Episkopa

V'sepredel'ni S'bor' s'v'kuplaet,

Da potrebit' raskol'i neveru,

Da s'edinit' i s'beret' uspeš'no

Pod' edinu cr'k'v'nuju stegu

Tol' ver'niki, toli svećeniki;

Eda v'kup'no s' vr'hov'nim' Pastirem'

Svetim' Ot'cem' L'vom' trinades'tim'

Ed'no suće veroju, naukom',

V'seveč'noe polučet' blažen'stvo. 
P

1 Dek. 1883.

II.

Slavjem L'vu XIII

V'semudri L've, vr'hov'ni Pastirju,

Bivaej slavnim Petra Namjestnikom, //v' dele Petrovim' s'lednikom'//

Ašte že Cr'k'vi sudiem', a miru

V'sem čelnikom';

V'nemli! Sloven'ski, hvalu daet' nebi,

V'kupa že s' inem, narod' goračaiši,

Egože vera znaema est' Tebe,

I trud' množaiši.

S'mer'ni ti narod Kurila, Metoda,

Plešćet' i poet', Arhiereistva radi

Slav'na Tvoego, Pet'deseta goda,

Pesmi nasladi.

Plešćet' i poet', Ti bo svetim' emu

„Nalogom' veliim“،, ezik' naznamena,

Svetuju Bratu č'st'na, miru v'semu,

V'zglasi imena.

Drevle Hr'stianstva Pred'stanoju v'zvjesti

Ti, da Slovenin' be i bor'cem' smjernim;

Ašće (?) Be, budet' v'segda v' Tvoei česti

Voinom' v'severinim.

Ešte s' narodom', i Tretago Čina, (?)

Franovac' m'nših, ta sloven'ska četa

Slavit' d'n's' Tebe, g'rdimi nevina

Užeti s'peta.

I ako prežde Cr'k'v' Petra radi,

Molit', da s Hr'stom' pobedu n'zriši,

L'va siloju nečist'nih vrag' kladi

V'se da s'krušiši. 
III.

Columbus noster est

Treti Čin sv. Fr. Kolumbu i Lavu XIII

Se Div' zemle, ezik' neznaemih'

Prouvêdev' srêtno obrêtaet';

Stran množaiših' zlatom sijaemih'

Diveštu se miru otkrivaet'.

Ki bê muž t' velii? Mir' ispita:

Bê Kolumbo: otvêt est povêsti:

Moj bê sin, moego st'bla kita

Italia hvalbêno v'zvêsti.

N' divnêe Kolumbovi slava,

Vêčnago iz' Rima v'sjudu v'siê,

Egda v'zg'rmit' glas' mudrago Lava,

Naš' Kolumbo est', v' nas' bo s'zriê.

Velii ei t' muž', n' togo radi, Ašće vêri revnost' Isusovi

I us'rdi, da v'seč'ska v'radi

Êko blažil bi te zemle novi.

Slav'n' ei t' muž', n' togo radi

Ašće H'rsta i Frančiška znaki

Križem' i poêsom' svêtlo v'sadi

Gdê bê prežde l'st' i užas' v'saki

A d'nes' ime divno Kolumbovo

Slagaetv se s' L'vovim dražestno

L'vu slavu se veličit' slovo

Obrêtnika Rim' proslavi č'stno

Ašće (zane) slavlen' i slavlenik' čedna

V' Frančiškovê esta bratra činê,

Kima plešćet', poet tretoredna

Čelad' pêsmi radostnêe ninê. 
Naš Kolombo: v'strubi L'v' iz Rima:

A s' Kolumbom' bratia v'sklicajut'

Naš L'v' est', dična slava vvsima

Iže H'rstu i Franu podražajut'.

V'zdažd' se ubo v' našem d'nes' narodê

L'vu hvala, č'st, blagodêt' prava:

V' petdesetom Osvećenija godêe

V'si da v'skliknem' silnu L'vu slava!

Prilog br. 5.

Giubileo Sacerdotale di S. S. Leone XIII, 1888.

Voti ed aspirazioni del pellegrino Italiano.

Kud kreće množina naroda,

Kamo ' 1 hrli svetom pobožnosti?

Čuda vela davno nečuvena,

Divne zgode davno nevidjene!

Koliko se stere Italija

Ća od Alpa do južnoga mora

Od sred-zemnog do jadranskog žala

Sve to vrvi k Rimu bijelome A pred noge Papi Velikome; Jedna misal, jedna vlada želja

U bezbrojnih hodočastnih srdcih,

Trinadesetog da posjete Lava

Što Petrovom upravlja Stolicom.

Da izkažu čuvstvo prirodjeno

Jeda mu se sloboda povrati

Kû mu svjetska uzkraćuje sila,

Da u Rimu sa svoga središta

I ko Vladar i Namjestnik Božji

Bez utruhe ine ljudske vlasti

Sam svoj bude i dušom i tjelom;

Odkud širi nauk ćudoredni

I tumači svete vjere članke

Katoličkoj vasionskoj Crkvi.- 
Da će Višnji Tvorac prikratiti

Tužne danke, a pospješit bolje

U sred Rima svome Namjestniku,

To nam želja, to nam krepka nada!

DP

Prilog br. 6 .

Castnomu Otcu Karlu Parčiću u Zadar

Od njegova Ujca Josipa Ant. Petriša

od Verbnika. Pozdrav

Sto $\mathrm{Te}=\mathrm{j}$ Lete opojio

$\mathrm{S}$ - zabitljivim vodam mutnim,

Il dumboki san Zgrabio

I čapukam i čeljustim?

Il si zgubil Sivrnicu,

Zvezdu milu i vodeću,

Ter ne poznaš ni Danicu

Koje kažu put hodeću?

Il ne čuješ Otačbinu

Tvoju majku naj vridniju

Il ne poznaš da rodbinu

Imaš Tvoju naj miliju?

Zač se nećeš potruditi

Otačbinu pohoditi,

I Rodbinu poljubiti

Prijatel razveseliti?

Istinaje da neć Otca,

Ni Majke najt, ka Te rodi

Jer se ona, kaj svim opća,

Smrtna zgoda njima zgodi.

Ali uprav zato silna

Želja mora Tebe budit

Za zemljicu, ka pokriva

Njih kopšćice, dojt pokropit. 
Onih kosti, koji dok-god

Ovog svita zrak zdihahu.

Željno, skrbno za Tve dobro

Trudihuse i nastjahu.

Znam, da Ti kad Bogu davaš

Aldov u Sve-svetoj Misi

Njihovih se Duš spominaš:

I neka Te Bog usliši.

Vindar imaš živu Bratju

Kih utroba rodi ista

Ista prsa njih dojahu

Ka i Tebe, ona čista!

Ovi Bratja Tebe često

Maljahnoga celivahu

I od mista $\mathrm{v}$ - drugo misto

Za zabavljat prenošahu.

Oh! Kak vruće i sad žele

Tebe oni ugljedati,

I preželjno kako hlepe,

Te zagarlit i lebzati!

Da njim nebi sinje more,

I Velebić zapričeti

I visoke druge gore

Oni bi Te pohajali!

Ali to i skrb obiteli

Neda njimse z doma dilit

Jer bi dicu zapustili

Ako bi to htili činit!

Ter nemoguć drugačije

U duhu Te celivaju

I što mogu naj snižnije

Tebi se priporučaju.

I njihova mala Dica

Svi preželjno izčekuju 
Za poznati Tvoja lica

I tvu ruku da celuju.

Eto Ti sad Bratučeda

Grškovića tamo tvoga

Da poljubi Tebe rada

Na misto od nas svakoga.

Bratučeda Tvoga Iva

Ljubko primi, drago celuj

I od desne i od liva

Svim na pozdrav tako daruj

Po njem primi celov bratje

Tete Anze i mene Ujca

Doklam hipom ni moguće

Lobzat tebe svog sinovca.

A pak na put pripravise

Za u hipu nas dojt lebzat

Prije neg smrt pripetise

Zadovoljstvo pridi nam dat.

Peto=letjah Petnaest priči

Teti i meni prit do Tebe!

Ti razumi moje riči

Razveselit oćeš sebe

Greš li morem, greš li krajem

Nasladjenje oku najdeš

I Verbnik mnogo ponovljen

Vidit oćeš kada dojdeš.

Vidit oćeš Lice Grada

Da ni ono koje biše

Gljedajući od zapada

Kad ga Ti izmalat htiše.

Ja sam v tujih rukah gljeda

To malanje Tvoje delo 
I uprav sem u njem poznal

Daje dobro i lipo verlo.

I ako mi hoćeš dati

Jedan izvod dela onoga

Jako drago ću imati

Tu spominu dela Tvoga

Al valja da opet dojdeš

Od poludne na malati

Ter i drugo lice oćeš

Od Verbnika izkazati.

Daj! Ter i Ptić gnjizda svoga

Nije nikad spozabio,

Nit je grma zelenoga

Zabil, u kom se rodio!

Može, i leti kud god hoće,

I nad leta stabla i drivja

Ljubi svitja ljubi voće

Pak se k svomu gnjizdu svija.

I onomu malom grmu

Ki njegovo gnjizdo skriva

Oh! Kako se lipo njemu

Klanja, termu lipo piva.

Voda svaka i Rika v-more

Povraća se i se zliva

Jer su iz mora nje izvore

Zato gre da ga celiva.

I Ti za to neć len biti

Neg ćeš častit Otačbinu

Dojti oćeš pohoditi

I zagrlit nas Rodbinu.

O sinovče, metim toga

Moli naše za spasenje

I za srićno odlazenje

$\mathrm{Z}$ ovog svita himbenoga. 
Primi ova pozdravljenja

Gluha, slipa Ujca tvoga

Osmi dan miseca svibnja

Osam sto Šestdeset Drugoga.

J A P (Josip Anton Periš)

Prilog br. 7.

Odgovor Dragutina Antuna Parčića svom ujaku Josipu Antunu Petrišu.

Odgovor

Miloglasna jedna ptica

Čudnovata crna i bila

K Manastiru od Školjića

Iznenada doletila!

Jedanaesti danak svibnja

$\mathrm{Na}$ dospitku jur biaše

Kad mi ova ptica divna

Lipu pisan pripivaše.

Nij' to ptica, pobratine, Nego pozdrav na listaku

Koga šalje z'Otačbine

Ujac dragi svom Netjaku.

Netom primih knjigu milu

Pročitah ju s desna s liva

Ter probudih moju vilu

Da i ona štogod piva!

Spominjem se domovine

Spominjem se prijateljah

I još moje sve Rodbine

I primilih Roditeljah.

Ali jaoh! Smrt nemila

Otca, Majku i Mihovila

I Osipa umorila,

Mene vrlo raztužila! 
Pak žalosti srca moga

Ja nemožem odoliti,

Niti mista rodjenoga

Željnim srcem pohoditi;

Što će grana kad nij' stupa,

Što će stablo kad nij’ žilah?

Mora jedn'i drugo skupa

Uvehnuti od sušila.

Nejmam srca pristupiti

Do mog stana najdražjega

Kada mislim zagrliti

Koga ištem, a nije ga.

Volim tužan iz daljine

U žalosti duše moje

Vapit srca iz dubine:

„Neka Bog ih pomiluje,

da bi pokoj vičnji njima

Milost Božja udilila

Svitlost vičnja iz visinah

Za uvike njim svitlila“ -

Istina je, da kod kuće

Brat i sestra još boravi,

Kojim zdravlje želim vruće

I bratinske plam ljubavi,

Drago jesti srcu momu

Jošter sada spominjati

Kak'u gnjizdu malenomu

Ditinska nas ljubav prati,

Kako mene malahnoga

Priljubezno celivahu, $S$ jednog mista do drugoga

$\mathrm{Za}$ zabavljat prenašahu.

Vrime lipo, lita blaga 
Kud prodjoste? Kako sada Srcem mojim jošter draga Uspomena vaša vlada!

Al Redovsko me življenje U naprid mi nedopušta

Da ne možem pohodjenje Mojima činit više s gusta.

Svak bo Raj po smrti žudi Vičnju slavu zadobiti

Valja da se i potrudi

Sve dužnosti izpuniti.

Bratji mojoj do istine

Srično i blago ja življenje

Vruće želim; a za time

Duše vičnje sahranjenje.

Neka rade, neka trude

Mučnim znojem čela svoga

I stostruko da njim bude

Blagoslovljen trud od Boga.

Virujte mi da udilje Ja bih, Ujče priljubljeni Izpunio vaše htinje, $\mathrm{Al}$ to dato nije meni;

Jer pri sebi nejmam sliku Niti znadem jel'kod koga $\mathrm{Ku}$ izmalah u Vrbniku S' onog boka Japnenskoga.

$\mathrm{r} / \mathrm{v}$

Ali da mi Bog podade Jošter jednom tamo iti S Makinom ću te kuntrade Čudnovatom pohoditi. Uzrokuje zrak svitline 
Da se u tren tu naslika

Polje, brdo, i doline

I čovičja još prilika.

Na staklašcu malahnomu

Jesu kuće, jesu driva

Narav ista po čudnomu

Dilovanju tu pribiva.

Čudnovata ta Makina

Fotografička se zove

Jerbo čini da svitlina

Kroz nju slika stvari nove.

Onda ću ja lice Vaše

Sa radošću naslikati

Ujca moga side vlase

Za uspomenu namalati.

Da Vas dakle Bog požive

Da se jošter mi vidimo

Da na svitu dok se žive

Skupa se razveselimo.

Drugo će vam još kazati

Bratučed, koj list donaša

I pismom će pripivati

Ako bude želja vaša, Od Mostira od Školjića

I od Zadra bilog grada

Spod planine Velebića,

Dalmaciom koji vlada.

Kakovo je selo od Prika,

Kaštel svetog Mihovila

Kakova je Puntamika

Kazat će vam njegva Vila.

Pozdrav budi moj srčeni, Svoj Rodbini sad poredom, Sestri i mužu, bratu i ženi, Teti, Ujni i bratučedom. 
Knjigu moju sad dospivam

Svibnja dne osamnajstoga

Svako dobro Vam nazivam

Od milosti Svemogoga.

Ujče, dragi želim vruće

Poživio nam na dugo.

Pisah u lito tisuće

Osam sto šestdeset drugo.

F. Ant. Parčić

\section{Bibliografija}

BOLONIĆ, Mihovil. 1965. Parčićeva tiskara u Glavotoku. Rijeka: Matica Hrvatska Pododbor u Rijeci.

BOLONIĆ, Mihovil. 1972. O životu i radu Dragutina A. Parčića. U povodu 70. obljetnice smrti. Bogoslovska smotra XLII/4: 413-433.

BOLONIĆ, Mihovil. 1982. Život i djelo Dragutina Antuna Parčića. Croatica Christana periodica IV/10: 172-188.

BOZANIĆ, Anton. 2012. Svećenici i župe na području Krčke biskupije od 1900. godine do danas. Krk: Biskupija Krk.

DAROSLAV (= Klement Kvirin BONEFAČIĆ). 1903. Dragutin A. Parčić 26. V. 1832. -25. XII. 1902. Krk: Kurykta.

GOSTL, Igor. 1998. Dragutin Antun Parčić [Mala knjižnica Matice hrvatske. Kolo 8., knj. 47.]. Zagreb: Matica hrvatska.

PETRIS, Josip Antun. 2010. Nike uspomene starinske. Prir. Tanja Perić-Polonijo. ZagrebRijeka: Institut za etnologiju i folkoristiku, Glosa.

TERRAGNI, Giovanni. Magistero e migrazioni. www.chiesacattolica.it/cci_new_v3/ s2magazine/vedidocAreaRiservata.jsp?id_allegato $=50118$ (posjet 17. 7. 2015).

The Hierarchy of the Catholic Church. www.catholic-hierarchy.org/bishop/bpecci.html (posjet 17. 7. 2015).

The Hierarchy of the Catholic Church. www.catholic-hierarchy.org/bishop/brajc.html (posjet 19. 7. 2015).

VELČIĆ, Franjo. 2004. Rukopisna ostavština „Staroslavenske akademije“ koja se čuva u Krku. U Glagoljica i hrvatski glagolizam. Zbornik radova s međunarodnoga znanstvenog skupa povodom 100. obljetnice Staroslavenske akademije i 50. obljetnice Staroslavenskog instituta (Zagreb-Krk, 2.-6. listopada 2002.), ur. Marija-Ana Dürrigl, Milan Mihaljević, Franjo Velčić, 37-52. Zagreb-Krk: Staroslavenski institut, Krčka biskupija. 


\section{Quaderno manoscritto Poemata e altre opere poetiche da Carlo Antonio Parcich}

Nel archivio diocesano di Krk (BAK) si conservano diversi scritti dell' insigne filologo croato Dragutin Antun Parčić - Carlo Antonio Parcich (Vrbnik, 1832 Roma, 1902). Come uomo di interesse enciclopedistico, scrittore ed editore di diverse grammatice e vocabolari italo-croati, e specialmente del Missale glagolito in lingua paleoslava, stampato a Roma nel 1893, si interessava pure della botanica, astronomia, fotografia ecc. Tra diverse affinità, era pure poeta e le sue poesie sono tuttora sparse fra il suo materiale archivistico oppure stampate come panegirici in diverse occasioni (ordinazioni sacerdotali ed episcopali, poesie in forma di lettere in rima ecc.). In questo lavoro viene particolarmente trascritto il suo quaderno di poesie intitolato: Poemata, e scritto a Zadar - Zara tra il 1848 ed il 1852. Tra l'altro, la curiosità sta nel fatto che queste poesie sono scritte in lingua italiana, latina e greca. Vengono pure presentate le poesie posteriori scritte in lingua paleoslava, croata ed italiana. Tra i suoi esperimenti poetici possiamo annoverare l'inizio della traduzione in lingua croata della Divina comedia di Dante Alighieri e la stampa esperimentale da lui fatta nel 1875 nel convento di Glavotok nel isola di Krk - Veglia, nella stamperia da lui eretta e chiamata „Serafinski tisak - Stamperia serafica“. Diverse sue poesie sono dedicate sia al papa Leone XIII, il quale ha dimostranto grande stima e simpatia verso i popoli Slavi con la sua enciclica Grande munus, sia agli particolari avenimenti ecclesiali di storica importanza.

\section{The Manuscript Collection Poemata and Other Poetic Works of Dragutin Antun Parčić}

A small manuscript collection Poemata of the excellent Slavonic linguist and Glagolitic scholar Dragutin Antun Parčić $(1832$ - 1902) is kept in the archival legacy of the Old Slavonic Academy in Krk, stored in the Bishop's Archives in Krk (BAK). The hand-made booklet contains 20 poems from Parčić. They all reflect their zeitgeist, and were written for various festive occasions, e. g. in honour of the Austrian emperor Ferdinand, of Urban Stanić, the teacher of Parčić from Zadar, and the like. What makes his collection special, is the fact that he wrote in as many as 3 languages: Italian, Latin and Greek. Although they are mostly school creations, written in his $16^{\text {th }}$ or $17^{\text {th }}$ year of life, they reveal to us the soundness and excellence of the language teaching of that time, as well as the talent of Parčić. His poems composed in the Croatian and Old Slavonic tongue are, for their part, of greater significance. Some of his letters written in lyric verse also belong here. In them one discovers some lesser- known biographical data on Parčić, as well 
as his love and loyalty for the pope Leo XIII who showed special affection for the Slavonic nations and their Old Slavonic culture, having elevated the worship of the Holy Brothers Cyril and Methodius to the level of the whole Church. His attempt at translating the Divina commedia of Dante is to be counted among his poetic body of work too. He, to use his own words, has put it in our language for a trial, i.e. he translated it into Croatian, and printed it experimentally in 1875 in his printshop in the tertiary monastery in Glavotok on the island of Krk.

Parole chiave: Dragutin Antun Parčić (Carlo Antonio Parcich), quaderno manoscritto Poemata, Urban Stanić (Urbano Stanich)

Keywords: Dragutin Antun Parčić - Carlo Antonio Parcich, the „Poemata“ collection, Urban Stanić - Urbano Stanich

Ključne riječi: Dragutin Antun Parčić, zbirka Poemata, Urban Stanić

Franjo Velčić

Teologija u Rijeci

Područni studij Katoličkoga bogoslovnog fakulteta Sveučilišta u Zagrebu HR-51000 Rijeka, Omladinska 14 franjo.velcic@ri.t-com.hr 


\section{FILOZOFSKI FAKULTET SVEUČILIŠTA U ZAGREBU \\ ZAVOD ZA HRVATSKU POVIJEST \\ INSTITUTE OF CROATIAN HISTORY \\ INSTITUT FÜR KROATISCHE GESCHICHTE}
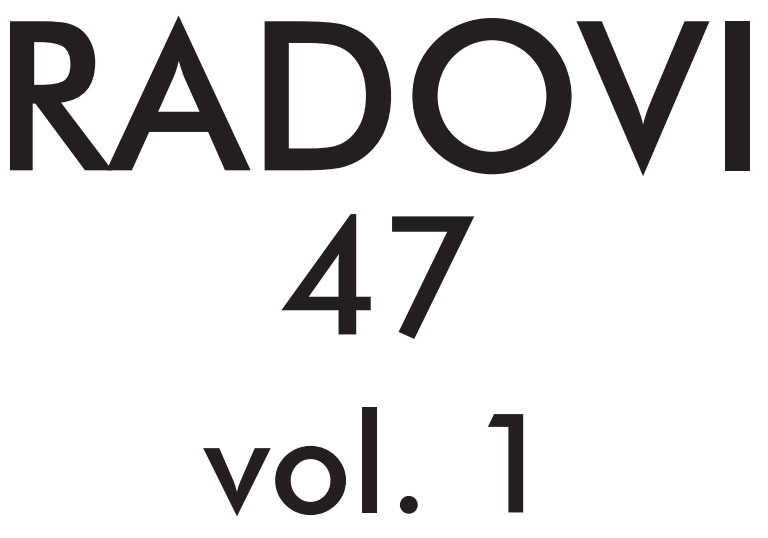

ZAVOD ZA HRVATSKU POVIJEST

FILOZOFSKOGA FAKULTETA SVEUČILIŠTA U ZAGREBU

\section{PF press \\ ZAGREB 2015.}




\title{
RADOVI ZAVODA ZA HRVATSKU POVIJEST FILOZOFSKOGA FAKULTETA SVEUČILIŠTA U ZAGREBU
}

\author{
Knjiga 47, vol. 1
}

\author{
Izdavač / Publisher \\ Zavod za hrvatsku povijest \\ Filozofskoga fakulteta Sveučilišta u Zagrebu \\ FF-press \\ Za izdavača / For Publisher \\ Vlatko Previšić \\ Glavni urednik / Editor-in-Chief \\ Hrvoje Gračanin \\ Izvršna urednica / Executive Editor \\ Inga Vilogorac Brčić \\ Uredništvo / Editorial Board
}

Bruna Kuntić-Makvić (stara povijest/ancient history), Zrinka Nikolić Jakus (srednji vijek/ medieval history), Hrvoje Petrić (rani novi vijek/early modern history), Željko Holjevac (moderna povijest/modern history), Tvrtko Jakovina (suvremena povijest/contemporary history),

Silvija Pisk (mikrohistorija i zavičajna povijest/microhistory and local history),

Zrinka Blažević (teorija i metodologija povijesti/theory and methodology of history)

Međunarodno uredničko vijeće / International Editorial Council

Denis Alimov (Sankt Peterburg), Živko Andrijašević (Nikšić), Csaba Békés (Budapest), Rajko Bratož (Ljubljana), Snježana Buzov (Columbus, Ohio), Svetlozar Eldarov (Sofija), Toni Filiposki (Skopje), Aleksandar Fotić (Beograd), Vladan Gavrilović (Novi Sad), Alojz Ivanišević (Wien),

Egidio Ivetić (Padova), Husnija Kamberović (Sarajevo), Karl Kaser (Graz),

Irina Ognyanova (Sofija), Géza Pálffy (Budapest), Ioan-Aurel Pop (Cluj),

Nade Proeva (Skopje), Alexios Savvides (Kalamata), Vlada Stanković (Beograd), Ludwig Steindorff (Kiel), Peter Štih (Ljubljana)

Izvršna urednica za tuzemnu i inozemnu razmjenu / Executive Editor for Publications Exchange Kristina Milković

Tajnik uredništva / Editorial Board Assistant

Dejan Zadro

Adresa uredništva/Editorial Board address

Zavod za hrvatsku povijest, Filozofski fakultet Zagreb, Ivana Lučića 3, HR-10 000, Zagreb

Tel. ++385 (0)1 6120 150, 6120 158, faks ++385 (0)1 6156879

Časopis izlazi jedanput godišnje / The Journal is published once a year

Časopis je u digitalnom obliku dostupan na / The Journal in digital form is accessible at Portal znanstvenih časopisa Republike Hrvatske „Hrčak“ http://hrcak.srce.hr/radovi-zhp

Financijska potpora za tisak časopisa / The Journal is published with the support by

Ministarstvo znanosti, obrazovanja i športa Republike Hrvatske

Časopis je indeksiran u sljedećim bazama / The Journal is indexed in the following databases:

Directory of Open Access Journals, EBSCO, SCOPUS, ERIH PLUS 
Naslovna stranica

Iva Mandić

Grafičko oblikovanje i računalni slog

Marko Maraković

Lektura

Samanta Paronić

Tisak

Web2tisak, Zagreb

Naklada

250 primjeraka

Časopis je u digitalnom obliku dostupan na Portalu znanstvenih časopisa Republike Hrvatske ,Hrčak“ http://hrcak.srce.hr/radovi-zhp

The Journal is accessible in digital form at the Hrcak - Portal of scientific journals of Croatia http://hrcak.srce.hr/radovi-zhp 


\section{RADOVI 47}

\section{vol. 1}

ZaVoda za hrVAtSku poviJest FILOZOFskoga fakulteta SVeuČILIŠTA u Zagrebu 


\title{
Tematski blok / Themed issue
}

\section{TREĆOREDSKA GLAGOLJAŠKA TRADICIJA U EUROPSKOM KONTEKSTU TERTIARY GLAGOLITIC TRADITION IN EUROPEAN CONTEXT}

\author{
Radovi međunarodnoga znanstvenog skupa \\ održanoga 27. i 28. IX. 2013. na Hrvatskom katoličkom sveučilištu u Zagrebu \\ u organizaciji \\ Provincije franjevaca trećoredaca glagoljaša u Zagrebu, Hrvatskoga katoličkog \\ sveučilišta u Zagrebu, Filozofskoga fakulteta Sveučilišta u Zagrebu - Odsjek za \\ povijest, Filozofskoga fakulteta Sveučilišta u Splitu - Odsjek za povijest, Instituta \\ za povijest umjetnosti u Zagrebu i Staroslavenskoga instituta u Zagrebu \\ Proceedings of the International Scientific Conference \\ held on 27th and 28th September 2013 at the Catholic University of Croatia in Zagreb \\ and organized by \\ the Province of the Glagolitic Friars of the Third Order Regular, Catholic University \\ of Croatia in Zagreb, Faculty of Humanities and Social Sciences of the University \\ of Zagreb - Department of History, Faculty of Humanities and Social Sciences of \\ the University of Split - Department of History, Institute of Art History, \\ and Old Church Slavonic Institute
}

Gosti urednici / Guest editors

\author{
Ivan BOTICA \\ Tomislav GALOVIĆ \\ Kristijan KUHAR
}

